Gynecologic and

Obstetric Investigation
Gynecol Obstet Invest 2004;58:207-211

DOI: $10.1159 / 000080073$
Received: February 10, 2004

Accepted after revision: May 31, 2004

Published online: August 4, 2004

\title{
Human Amniotic Fluid Glycoproteins Expressing Sialyl Lewis Carbohydrate Antigens Stimulate Progesterone Production in Human Trophoblasts in vitro
}

\author{
Udo Jeschke $^{a}$ loannis Mylonas ${ }^{a}$ Dagmar-Ulrike Richter ${ }^{b}$ Annett Streu ${ }^{b}$ \\ Heiner Müller ${ }^{b}$ Volker Briese ${ }^{b}$ Klaus Friese ${ }^{a}$ \\ a 1st Department of Obstetrics and Gynecology, Ludwig Maximilian University of Munich, Munich, and \\ ${ }^{b}$ Department of Obstetrics and Gynecology, University of Rostock, Rostock, Germany
}

\section{Key Words}

Amniotic fluid glycoproteins · Progesterone production • Trophoblast cells

\begin{abstract}
Background: Progesterone is thought to mediate immune modulator effects by regulating uterine responsiveness. The aim of the study was to clarify the effect of transferrin and glycodelin A (former name PP14) as sialyl Lewis $\mathrm{X}$-expressing glycoproteins on the release of progesterone by trophoblast cells in vitro. Methods: Cytotrophoblast cells were prepared from human term placentas by standard dispersion of villous tissue followed by a Percoll gradient centrifugation step. Trophoblasts were incubated with varying concentrations $(50-300 \mu \mathrm{g} /$ $\mathrm{ml}$ ) of human amniotic fluid- and serum-transferrin as well as with glycodelin $A$. Culture supernatants were assayed for progesterone, human chorionic gonadotropin (hCG) and cortisol by enzyme immunometric methods. Results: The release of progesterone is increased in amniotic fluid transferrin- and glycodelin A-treated trophoblast cell cultures compared to untreated trophoblast cells. There is no relation between transferrin and the
\end{abstract}

hCG or cortisol production of trophoblast cells. Conclusion: The results suggest that sialyl Lewis carbohydrate antigen-expressing amniotic fluid glycoproteins modulate the endocrine function of trophoblasts in culture by upregulating progesterone production.

Copyright (C) 2004 S. Karger AG, Basel

\section{Introduction}

During pregnancy the immune response of the mother against certain antigens is reduced $[1,2]$. Progesterone is one of a variety of molecules that regulate uterine immune responsiveness $[3,4]$ by inhibiting the inflammatory response [5]. The suppression of mixed lymphocyte culture responses by progesterone has also been described [6]. Due to its lipid solubility, progesterone incorporates into the lymphocyte plasma membrane interfering with membrane dynamics [7]. This promotes a locally suppressed activity at the maternal-fetal frontier [8].

In most mammals, progesterone production is initially located in the corpus luteum of the ovary, shifting to the trophoblast as pregnancy proceeds. Progesterone biosynthesis in the human placenta is regulated by a variety of

\begin{tabular}{ll}
\hline KARGER & ( ) 2004 S. Karger AG, Basel \\
0378-7346/04/0584-0207\$21.00/0 \\
$\begin{array}{l}\text { Fax +4161306 12 34 } \\
\begin{array}{l}\text { E-Mail karger@karger.ch } \\
\text { www.karger.com }\end{array}\end{array}$ & $\begin{array}{l}\text { Accessible online at: } \\
\text { www.karger.com/goi }\end{array}$
\end{tabular}

Dr. Udo Jeschke

1st Department of Obstetrics and Gynecology, Ludwig Maximilian University of Munich Maistrasse 11

DE-80337 Munich (Germany)

Tel. +49 895160 4266, Fax +49 895160 4916, E-Mail udo.jeschke@med.uni-muenchen.de 
hormones. Progesterone synthesis is also regulated by estradiol-17 $\beta$ and autoregulated by progesterone itself [4]. Feinberg et al. [8] showed that progesterone production was significantly stimulated by interleukin (IL)- $1 \alpha$, IL- $1 \beta$ and tumor necrosis factor- $\alpha$ (TNF- $\alpha$ ) in chorion carcinoma cells. In addition, progesterone also plays a role in the maintenance of pregnancy, and administration of progesterone is able to prevent preterm delivery $[9,10]$.

During gestation, the fetus requires large amounts of iron. The major iron source is maternal serum transferrin $[11,12]$. Transferrin-dependent iron transfer is mediated by transferrin receptors, which are present on the maternal-facing plasma membrane and on the fetal-facing basal plasma membrane of placental syncytiotrophoblasts [13, 14].

Glycodelin, previously known as placental protein 14 (PP14), is an approximately $28-\mathrm{kD}$ glycoprotein with a unique carbohydrate configuration, consistent with sialylated LacdiNAc structures that are very unusual for mammals [15]. Glycodelin is a major reproductive glycoprotein with several functions in cell recognition and differentiation [16]. Under physiological conditions glycodelin is mainly synthesized in secretory endometrial glands [17, 18] and gestational decidua [19]. Although the precise function of glycodelin A has still not been elucidated, it can inhibit the activity of natural killer (NK) cells [20] and therefore play a major role during implantation and the early development of the fetal-placental unit. Interestingly, glycodelin A levels rise rapidly in early pregnancy, with the highest concentrations being found in the decidua between the 6th and 12th week of gestation [21], suggesting important function in early pregnancy.

In the present study, we investigated the influence of the human amniotic fluid glycoprotein transferrin, human holo-serum transferrin and apo-serum transferrin and glycodelin A on progesterone release of trophoblast cells in vitro.

\section{Materials and Methods}

\section{Purification of Transferrin from Amniotic Fluid (hAFT)}

Human amniotic fluid transferrin (hAFT) was purified as previously published [22]. Briefly, amniotic fluid was dialyzed and fractionated on a DEAE-Sepharose (Amersham Biosciences, Uppsala, Sweden). Transferrin-containing fractions were further purified on Superdex 75 (Amersham Biosciences). Subsequently, transferrincontaining material was applied to a protein A column (Amersham Biosciences) to remove the remaining IgG. Monoclonal antibodies directed against human chorionic gonadotropin (hCG; Dianova, Hamburg, Germany) were coupled to CNBr-Sepharose 4B (Amersham Biosciences) to remove traces of hCG. Transferrin-containing material was applied to the column; the main fraction containing pure amniotic fluid transferrin was concentrated by ultrafiltration. The purity was checked by SDS-PAGE and N-terminal amino acid analysis. Quantification of the isolated transferrin was performed on a VITROS 250 analyzer (Ortho Clinical Diagnostics GmbH, Neckargemünd, Germany).

\section{Purification of Glycodelin A from Amniotic Fluid}

Glycodelin A was purified as recently published [23]. Briefly human amniotic fluid was dialyzed and fractionated on DEAESepharose (Amersham Biosciences). Glycodelin A was further purified on octyl-Sepharose Cl-4B (Amersham Biosciences). Final purification was achieved by hydrophobic interaction chromatography on Resource-Phe (Amersham Biosciences). Glycodelin A-containing fractions were concentrated by ultrafiltration.

\section{Culture of Trophoblasts}

Cytotrophoblast cells were isolated from term human placentas following spontaneous delivery or planned cesarean section and were processed according to Kliman et al. [24] with slight modifications [23]. Briefly, villous tissue was minced and transferred to a trypsin/ DNAse I mixture (142.4 mg trypsin and $5 \mathrm{mg}$ DNAse I; SigmaAldrich, Taufkirchen, Germany). The remaining tissue fragments were digested twice in trypsin/DNAse I solution (71.2 mg trypsin and $5 \mathrm{mg}$ DNAse I; Sigma-Aldrich). The cell suspensions obtained by the three digestion steps were pooled and loaded on a preformed Percoll (Amersham Biosciences) gradient. The density zone containing trophoblast cells was removed. The trophoblast identity of the isolated cells was confirmed by their ability to produce specific hormones (hCG, hPL and progesterone) and by immunostaining with an anticytokeratin antibody (anti-cytokeratin AE1/AE3; Roche, Mannheim, Germany). Viability of trophoblast cells was tested using a trypan blue exclusion assay (Sigma-Aldrich, Munich, Germany).

\section{Treatment of Trophoblast Cultures with hAFT, Serum}

Transferrin and Glycodelin $A$

Trophoblasts were adjusted to a cell concentration of $1 \times 10^{6}$ cells/ml in RPMI 1640 culture medium supplemented with $10 \%$ fetal calf serum and gentamycin $(200 \mu \mathrm{g} / \mathrm{ml})$ and incubated in the presence of varying concentrations $(50-250 \mu \mathrm{g} / \mathrm{ml})$ of amnion transferrin, varying concentrations $(100-300 \mu \mathrm{g} / \mathrm{ml})$ of human holo- and apo-serum transferrin (Sigma-Aldrich) and varying concentrations $(50-250 \mu \mathrm{g} / \mathrm{ml})$ of glycodelin A. The effect of the glycoproteins on the secretion of progesterone was studied by simultaneously comparing the kinetics of progesterone release of untreated (controls) and glycoprotein-stimulated trophoblast cell cultures. At designated times, aliquots of the culture media were removed, frozen at $-20^{\circ} \mathrm{C}$ and replaced with fresh medium. Cells were cultured for up to $64 \mathrm{~h}$.

\section{Identification of Secreted Hormones}

The analyzer SR1 from BioChemImmunoSystems GmbH determined the secretion of progesterone. Samples were diluted 1:3 with hormone-free diluents because of the intensively colored culture medium. The sensitivity and the intra-assay coefficient of variation of progesterone EIA $(<6.4 \mathrm{nmol} / 1$ and $6.8 \%$ at a medium value of $11.5 \mathrm{nmol} / 1 ; 5.4 \%$ at $65.6 \mathrm{nmol} / 1$, respectively) demonstrate the accuracy of the applied methods. 
Fig. 1. Effect of human amnion fluid transferrin (hAFT) and glycodelin A on the progesterone production of trophoblast cells in vitro. Data (mean $\pm \mathrm{SD}$ ) represent progesterone concentration in aliquots of the culture media at designated times, $n=4$ for each group. Differences between the controls and stimulated cultures are significant for cultures stimulated with 50,100 and $250 \mu \mathrm{g} /$ $\mathrm{ml} \mathrm{hAFT}(\mathrm{p}<0.002,0.002$ and 0.004$)$ and cultures stimulated with 100 and $250 \mu \mathrm{g} / \mathrm{ml}$ glycodelin A $(\mathrm{p}<0.001,0.001)$.

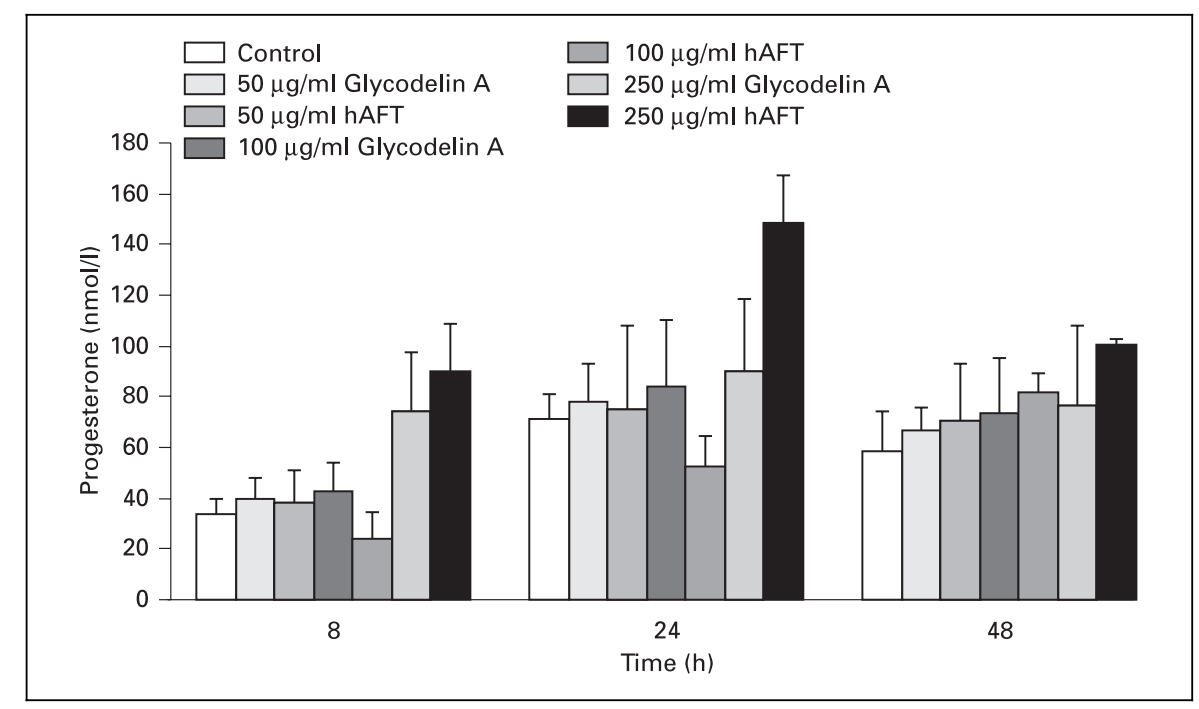

Statistical Analysis

The Wilcoxon's signed rank tests for paired samples was used to compare the means. Statistical computerization of the analysis utilized the SPSS software package (SPSS, Chicago, Ill., USA). $p<0.05$ was considered statistically significant.

\section{Results}

\section{Stimulation of Progesterone Production by hAFT and} Glycodelin A

Analysis of progesterone in stimulated and unstimulated cell cultures revealed that hAFT- and glycodelin A-stimulated trophoblast cells showed a higher secretion of progesterone compared to unstimulated cells over a cultivation period of $48 \mathrm{~h}$ (fig. 1). There was a significant difference between the progesterone production of stimulated and unstimulated cell cultures $(\mathrm{p}<0.002$ for $50 \mu \mathrm{g}$ hAFT, $\mathrm{p}<$ 0.002 for $100 \mu \mathrm{g}$ hAFT and $\mathrm{p}<0.004$ for $250 \mu \mathrm{g}$ hAFT). The stimulation effect of hAFT is dose-dependent. Cells stimulated with $250 \mu \mathrm{g} / \mathrm{ml}$ hAFT showed the highest stimulation effects compared to 100 and $50 \mu \mathrm{g} / \mathrm{ml}$ hAFT-stimulated cells. The relative stimulation with $50 \mu \mathrm{g} / \mathrm{ml}$ hAFT was $112.4 \%$, with $100 \mu \mathrm{g} / \mathrm{ml} \mathrm{hAFT} 119.4 \%$ and with $250 \mu \mathrm{g} / \mathrm{ml}$ hAFT $122 \%$ compared to unstimulated controls. The relative progesterone production of trophoblast cells stimulated by $50 \mu \mathrm{g} / \mathrm{ml}$ glycodelin A was not significantly different from unstimulated controls $(\mathrm{p}>0.4)$. In trophoblast cells stimulated with 100 and $250 \mu \mathrm{g} / \mathrm{ml}$ glycodelin A, the progesterone production was elevated to 185.5 and $240.8 \%$, respectively. These differences between stimulated cells and controls were significant $(\mathrm{p}<0.001$ and $\mathrm{p}<0.001)$.

\section{No Stimulation of Progesterone Production by Holo- and Apo-Serum Transferrin}

Over the cultivation period of $48 \mathrm{~h}$, trophoblast cells from two human term placentas stimulated with 100 and $300 \mu \mathrm{g} / \mathrm{ml}$ of apo- and holo-serum transferrin did not show an increase in progesterone production as compared to unstimulated controls ( $p>0.7$; fig. 2 ). In addition, we found that neither of the tested transferrins had an effect on the hCG or cortisol release of trophoblast cells (data not shown).

\section{Discussion}

At term, the human placenta produces approximately $300 \mathrm{mg}$ of progesterone and about $100 \mathrm{mg}$ of estrogens per day [25]. Progesterone facilitates the maintenance of pregnancy through a multitude of mechanisms, e.g. by acting on the myometrium and the uterine cervix. There is evidence that progesterone has immunosuppressive effects and regulates the cytokine network in the uterus [26]. Interestingly, IL- $1 \alpha$, IL- $1 \beta$ and TNF- $\alpha$ can significantly stimulate the progesterone production of the trophoblast tumor cell line JEG-3 [8]. However, in primary placental cells IL-1 $\beta$ had no effect on progesterone production [27]. Studies by Shanker and Rao [28] showed that incubation of cultured trophoblast cells with estradiol-17 $\beta$ increased progesterone production. The addition of the aromatase inhibitor CGS 16949 A and the estrogen receptor antagonist ICI 182780 inhibited progesterone production. RU 486 and ZK 98299, which are progesterone receptor 
Fig. 2. Effect of human holo- and apo-serum transferrin on progesterone production in trophoblast cells. Trophoblast cells stimulated with 100 and $300 \mu \mathrm{g} / \mathrm{ml}$ of holo- or aposerum transferrin showed no significantly different progesterone secretion compared to unstimulated controls ( $\mathrm{p}>0.7)$.

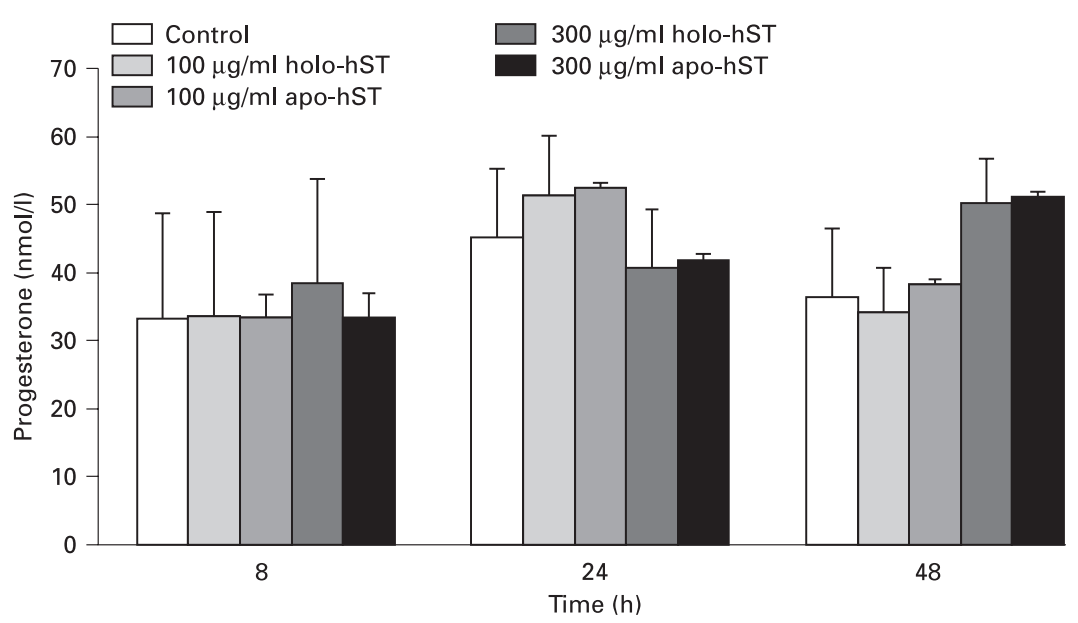

antagonists, also significantly modulated progesterone synthesis. Therefore, progesterone synthesis in the human placenta is regulated by estradiol-17 $\beta$ and autoregulated by progesterone itself. [28]. Osteogenic protein-1 (OP-1/ BMP-7), a member of the transforming growth factor (TGF- $\beta$ ) superfamily of proteins, reduced the secretion of progesterone in cytotrophoblast cultures of first-trimester and term placentas [29].

We demonstrate that hAFT and glycodelin A stimulate secretion of progesterone in human trophoblast cells in a dose-dependent manner. In a recent study we showed that both glycoproteins express sialyl Lewis carbohydrate structures and are able to block E-selectin [30].

Recently, it was demonstrated that human trophoblast cells isolated from term placentas synthesize transferrin [31]. This transferrin isolated from cytotrophoblast and syncytiotrophoblast cells was demonstrated to be different from both maternal and fetal serum transferrin. A higher degree of sialylation and an increase in branching was described in cytotrophoblast transferrin. This is in agreement with our findings of the carbohydrate structures in hAFT, suggesting that hAFT was produced by the trophoblast and secreted into the amniotic fluid and not into maternal circulation. In addition, human serum transferrin, isolated from pregnant women, does not contain ( $\alpha 1-3)$-fucosylated N-glycans [30]. Because hAFT contains ( $\alpha 1-3)$-fucosylated $\mathrm{N}$-glycans, representing sialyl $\mathrm{Le}^{\mathrm{X}}$ elements, it is able to bind to selectins as shown by our previous study [30]. Human trophoblast cells express L- and E-selectin [32, 33]. Therefore transferrin produced by trophoblast cells may act in a paracrine or autocrine fashion on trophoblasts and contribute to the amniotic fluid protein pool. Serum transferrin even if it is isolated from pregnant women does not contain ( $\alpha 1-3)$-fucosylated N-glycans and therefore does not stimulate progesterone production in trophoblasts. Glycodelin A also contains ( $\alpha 1-3)$-fucosylated $\mathrm{N}$-glycans, representing sialyl $\mathrm{Le}^{\mathrm{X}}$ elements. In addition, we were able to show that moderate and high concentrations of glycodelin A stimulate the progesterone production of trophoblast cells. Stimulation with hAFT elevated progesterone secretion. Surprisingly, also low concentrations of hAFT increased progesterone values significantly. The hAFT concentrations used in the experiments correspond with the transferrin concentrations in amnion fluid in vivo [34] and are lower than in human serum (factor 33.74). The low progesterone stimulatory effect of hAFT compared to glycodelin A correlates with our measurements on inhibition power of both glycoproteins in E-selectin-mediated cell adhesion [30]. Glycodelin A binds to E-selectin more efficiently compared to hAFT, suggesting a glycosylation in glycodelin that is more suitable to bind to selectins. Because hAFT and serum transferrin are only different in their glycosylation [22] and hAFT in contrast to serum transferrin contains ( $\alpha 1-3)$-fucosylated N-glycans, we assume that glycoproteins with these structures are able to stimulate progesterone production in trophoblast cells.

In summary, in this study we could show that glycoproteins expressing sialyl Lewis carbohydrate structures stimulate the progesterone production of trophoblast cells. In combination with previous data [31] that demonstrate the synthesis of differentially glycosylated transferrin by tro- 
phoblast cells, a paracrine or autocrine mechanism is suspected. In addition, our results indicate that glycodelin A may have paracrine effects in reproductive tissues and at the maternal-trophoblast interface. The precise mechanism of glycodelin A-trophoblast interaction is under investigation.

\section{Acknowledgements}

We thank Mrs. Eckerle and Mrs. Ertl for excellent technical assistance.

\section{References}

1 Entrican G: Immune regulation during pregnancy and host-pathogen interactions in infectious abortion. J Comp Pathol 2002;126:7994.

2 Hedge UC: Immunmodulation of the mother during pregnancy. Med Hypothesis 1991;35: 159-164.

3 Beagley KW, Gockel CM: Regulation of innate and adaptive immunity by the female sex hormones oestradiol and progesterone. FEMS Immunol Med Microbiol 2003;38:13-22.

4 Hansen PJ: Regulation of uterine immune function by progesterone - Lessons from the sheep. J Reprod Immunol 1998;40:63-79.

5 Siiteri PK, Febres F, Clemens LE, Chang RJ, Gondos B, Stites D: Progesterone and maintenance of pregnancy: Is progesterone nature's immunosuppressant? Ann NY Acad Sci 1977; 286:384-397.

6 Beer AE, Sio JO: Placenta as an immunological barrier. Biol Reprod 1982;26:15-27.

7 Mandler RN, Seamer LC, Domalewski MD, Bankhurst AD: Progesterone but not estrogen depolarizes natural killer cells. Nat Immun 1993;12:128-135.

8 Feinberg BB, Anderson DJ, Steller MA, Fulop V, Berkowitz RS, Hill JA: Cytokine regulation of trophoblast steroidogenesis. J Clin Endocrinol Metab 1994; 78:586-591.

9 Meis PJ, Klebanoff M, Thom E, Dombrowski MP, Sibai B, Moawad AH, Spong CY, Hauth JC, Miodovnik M, Varner MW, Leveno KJ, Caritis SN, Iams JD, Wapner RJ, Conway D, O'Sullivan MJ, Carpenter M, Mercer B, Ramin SM, Thorp JM, Peaceman AM, Gabbe S: Prevention of recurrent preterm delivery by 17 alpha-hydroxyprogesterone caproate. N Engl J Med 2003;348:2379-2385.

10 da Fonseca EB, Bittar RE, Carvalho MH, Zugaib M: Prophylactic administration of progesterone by vaginal suppository to reduce the incidence of spontaneous preterm birth in women at increased risk: A randomized placebo-controlled double-blind study. Am J Obstet Gynecol 2003;188:419-424.

11 Verrijt CEH, Kroos MJ, van Noort WL, van Eijk HG, van Dijk JP: Binding of human isotransferrin variants to microvillous and basal membrane vesicles from human term placenta. Placenta 1997;18:71-77

12 Starreveld JS, van Denderen J, Kroos MJ, van Eijk HG, van Dijk JP: Effects of iron supplementation on iron uptake by differentiating cytotrophoblasts. Reprod Fertil Dev 1996;8: 417-422.
13 Loh TT, Higuchi DA, van Bockxmer FM, Smith $\mathrm{CH}$, Brown EB: Transferrin receptors on the human placental microvillous membrane. J Clin Invest 1980;65:1182-1191.

14 Vanderpuye OA, Kelley LK, Smith CH: Transferrin receptors in the basal plasma membrane of the human placental syncytiotrophoblast. Placenta 1986;7:391-403.

15 Dell A, Morris HR, Easton RL, Panico M, Patankar M, Oehniger S, Koistinen R, Koistinen H, Seppala M, Clark GF: Structural analysis of the oligosaccharides derived from glycodelin, a human glycoprotein with potent immunosuppressive and contraceptive activities. J Biol Chem 1995;270:24116-24126.

16 Seppälä M, Taylor RN, Koistinen H, Koistinen R, Milgrom E: Glycodelin: A major lipocalin protein of the reproductive axis with diverse actions in cell recognition and differentiation. Endocr Rev 2002;23:401-430.

17 Julkunen M, Koistinen R, Sjoberg J, Rutanen EM, Wahlstrom T, Seppälä M: Secretory endometrium synthesizes placental protein 14. Endocrinology 1986;118:1782-1786.

18 Mylonas I, Speer R, Makovitzky J, Richter DU, Briese V, Jeschke U, Friese K: Immunohistochemical analysis of steroid receptors and glycodelin A (PP14) in isolated glandular epithelial cells of normal human endometrium. Histochem Cell Biol 2000; 114:405-411.

19 Julkunen M: Human decidua synthesizes placental protein 14 (PP14) in vitro. Acta Endocrinol (Copenh) 1986;112:271-277.

20 Okamoto N, Uchida A, Takakura K, Kariya Y, Kanzaki H, Riittinen L, Koistinen R, Seppälä M, Mori T: Suppression by human placental protein 14 of natural killer cell activity. Am J Reprod Immunol 1991;26:137-142.

21 Julkunen M, Rutanen E, Koskimies A, Ranta T, Bohn H, Seppälä M: Distribution of placental protein 14 in tissues and body fluids during pregnancy. Br J Obstet Gynaecol 1985;92: 1145-1151.

22 van Rooijen JJ, Jeschke U, Kamerling JP, Vliegenthart JF: Expression of N-linked sialyl Le(x) determinants and O-glycans in the carbohydrate moiety of human amniotic fluid transferrin during pregnancy. Glycobiology 1998;8: 1053-1064.

23 Jeschke U, Richter DU, Walzel H, Bergemann C, Mylonas I, Sharma S, Keil C, Briese V, Friese K: Stimulation of hCG and inhibition of hPL in isolated human trophoblast cells in vitro by glycodelin A. Arch Gynecol Obstet 2003;268:162-167.
24 Kliman HJ, Nestler JE, Sermasi E, Sanger HJ, Strauss JF: Purification, characterisation, and in vitro differentiation of cytotrophoblasts from human term placentas. Endocrinology 1986;118:1567-1582.

25 Zelewski L: Regulation of progesterone biosynthesis in human placenta. Acta Biochim Pol 1992;39:233-244.

26 Chwalisz K, Garfield RE: Role of progesterone during pregnancy: Models of parturition and preeclampsia. Z Geburtsh Perinat 1994;198: 170-180.

27 Seki H, Zosmer A, Elder MG, Sullivan MH: The regulation of progesterone and hCG production from placental cells by interleukin1beta. Biochim Biophys Acta 1997;1336:342348.

28 Shanker YG, Rao AJ: Regulation of progesterone biosynthesis in the human placenta by estradiol 17 beta and progesterone. Biochem Mol Biol Int 1997;43:591-599.

29 Martinovic S, Latin V, Suchanek E, StavljenicRukavina A, Sampath KI, Vukicevic S: Osteogenic protein-1 is produced by human fetal trophoblasts in vivo and regulates the synthesis of chorionic gonadotropin and progesterone by trophoblasts in vitro. Eur J Clin Chem Clin Biochem 1996;34:103-109.

30 Jeschke U, Wang X, Briese V, Friese K, Stahn $\mathrm{R}$ : Glycodelin and amniotic fluid transferrin as inhibitors of E-selectin-mediated cell adhesion. Histochem Cell Biol 2003;119:345-354.

31 Verrijt CEH, Kroos MJ, Verhoeven AJM, van Eijk HG, van Dijk JP: Transferrin in cultured human term cytotrophoblast cells: Synthesis and heterogeneity. Mol. Cell. Biochem. 1997; 173:177-181.

32 Milstone DS, Redline RW, O’Donnell PE, Davis VM, Stavrakis G: E-selectin expression and function in a unique placental trophoblast population at the fetal-maternal interface: Regulation by a trophoblast-restricted transcriptional mechanism conserved between humans and mice. Dev Dyn 2000;219:63-76.

33 Genbacev OD, Prakobphol A, Foulk RA, Krtolica AR, Ilic D, Singer MS, Yang ZQ, Kiessling LL, Rosen SD, Fisher SJ: Trophoblast L-selectin-mediated adhesion at the maternal-fetal interface. Science 2003;299:405408.

34 Crosignani PG, Tencioni T, Brambati B: Concentration of chorionic gonadotropin and chorionic somatomammotropin in maternal serum, amniotic fluid and cord blood serum at term. J Obstet Gynaecol Br Commonw 1969; 79:122-126. 